\title{
Exploration Study of Master's Degree Graduates of Sport Science Study Program of Faculty of Sport Science Yogyakarta State University in Job Acquirement
}

\author{
Sumaryanti Sumaryanti ${ }^{1, *}$, Duwi Kurnianto Pambudi ${ }^{1}$, Wawan Sundawan \\ Suherman $^{1}$, Sulistiyono Sulistiyono ${ }^{1}$, Satya Perdana ${ }^{1}$ \\ ${ }^{1}$ Faculty of Sport Science, Universitas Negeri Yogyakarta, Yogyakarta, Indonesia \\ ${ }^{*}$ Corresponding author.Email: sumaryanti@uny.ac.id
}

\begin{abstract}
Due to numbers of graduated alumni each years, a tracer study is required in order to understand the job absorption and to evaluate the performance of each study program. The advantage of tracer study is not only limited to the interest of university. It could also useful to give important information regarding the link between the world of education and the corporate world. Tracer study is capable to give a detailed information regarding the work suitability in either horizontally (between various disciplines) or vertically (between various level of education). Therefore, tracer study is beneficial to overcome the problem of job opportunity gap and to give the solution for the problem. Information regarding relevant competence in corporate world could potentially help creating a better curriculum and learning system for university. According to the data, there are 1 foreign student $(0.66 \%)$ from University of Burundi Institute of Physical Education and Sports, and 151 domestic students (99.33\%) with the 59.1\% majority (90 Students) are Yogyakarta State University bachelor's degree graduates who choose to continue their master's study in Faculty of Sport Science Yogyakarta State University, while 40.79\% (62 Students) of them coming from other university. This data shows the high rate of Yogyakarta Tate University bachelor's degree graduates who choose to continue their master's study. 110 students $(72.36 \%$ ) have work in various profession when continue their master's degree while $27.63 \%$ of them (42 Students) have not acquire a job. According to the data, there are various profession occupied by different numbers of students of master's degree program of Sport Science study program of Faculty of Sport Science Yogyakarta State University. Based on the data, $36.18 \%$ (55 Student) work as a teacher, $33.55 \%$ (51 Students) work as university lecturer, $15.13 \%$ (23 students) works in unrelated field, $5.92 \%$ (9 students) work as entrepreneur, $4.61 \%$ (7 students) work as professional coach, $2.63 \%$ (4 students) work as sport consultant, $1.32 \%$ (2 students) work as sports therapy expert, and $0.66 \%$ (1 students) works as a professional trainer.
\end{abstract}

Keywords: Tracer Study, Waiting Period, Job relevance

\section{INTRODUCTION}

College and Higher Educational Institution in Indonesia is a place to educate and prepare every young generation of leader for the future of Indonesia. Competent and qualified Human Resources that possess the forwardness to wade through the world of profession, patriotism, and society is one factor that determine the advancement of a country. A change is inevitable in human life. The same thing happens in the orientation of education which previously based on the idea of knowledge for knowledge's sake now had changed into knowledge for the sake of people's livelihood [1]-[3] .

As series of question often appears after a person finished their college. Some question such as 'where can 
I find work', 'where should I work', 'what do I work for' are only some frequently appear questions in people's mind. Those question indicates the change of awareness as well as a hope that the knowledge and skill sets that has been learned in college can provide benefits for other people [4], [5].

Same thing happens institutionally in which educational institutions are expected to deliver a real effort of acknowledging the nation shown by the ability to produce high-quality graduates who posses academic brilliance and graceful personality. To realize this noble ideals, educational institutions are expected to reorganized themself in order to increase the education service for the public. Several ways to increase the public's education service can be done through study program performance assessment by Higher Education National Accreditation Organization (BAN PT) and Self Evaluation report. Those two should act as a fundamental idea of organizational consolidation and the development of academic activity program [6], [7].

\section{METHOD}

Survey method is used to accomplish the goal of this study. In addition to that, questionnaires were used as data collection tool. The aim of this study is to understand the state of an object, in this case the profile of master's degree graduates of Sport Science study program of Faculty of Sport Science Yogyakarta State University.

Polls and questionnaires were used as data collection technique for this research. Questionnaires either in the printed forms or virtual form via Google Form were given to the object of this study. Data analysis technique used in this study are quantitative descriptive analysis combined with percentage [4], [7], [8].

\section{RESULT AND DISCUSSION}

Using Google form as the main source to collect data, researchers are able to collect 152 respondents which are consist of alumni who attended college between 2009 and 2019. According to the analyzed data, the result of the study can be presented as follows:

Table 1. Bachelor Degree University of Origin

\begin{tabular}{|c|l|c|c|}
\hline No & \multicolumn{1}{|c|}{ Asal Universitas } & Amount & \% \\
\hline 1 & UNY & 90 & 59,21 \\
\hline 2 & UNNES & 6 & 3,95 \\
\hline 3 & Universitas Jambi & 5 & 3,29 \\
\hline 4 & Universitas Bengkulu & 4 & 2,63 \\
\hline 5 & Universitas Negeri Malang & 4 & 2,63 \\
\hline 6 & Universitas Negeri Makassar & 3 & 1,97 \\
\hline
\end{tabular}

\begin{tabular}{|c|c|c|c|}
\hline 7 & UNS & 3 & 1,97 \\
\hline 8 & $\begin{array}{l}\text { STKIP Dharma Wacana } \\
\text { Metro }\end{array}$ & 2 & 1,32 \\
\hline 9 & IKIP Mataram & 2 & 1,32 \\
\hline 10 & UNESA & 2 & 1,32 \\
\hline 11 & Universitas Islam Riau & 2 & 1,32 \\
\hline 12 & Universitas Lampung & 2 & 1,32 \\
\hline 13 & Universitas Mulawarman & 2 & 1,32 \\
\hline 14 & Universitas Negeri Medan & 2 & 1,32 \\
\hline 15 & Universitas Palangka Raya & 2 & 1,32 \\
\hline 16 & Universitas Riau & 2 & 1,32 \\
\hline 17 & $\begin{array}{l}\text { University of Burundi Institute } \\
\text { of Physical Education and } \\
\text { Sports }\end{array}$ & 1 & 0,66 \\
\hline 18 & IKIP Budi Utomo Malang & 1 & 0,66 \\
\hline 19 & $\begin{array}{l}\text { STKIP Muhammadiyah } \\
\text { Kuningan }\end{array}$ & 1 & 0,66 \\
\hline 20 & STKIP PGRI Pontianak & 1 & 0,66 \\
\hline 21 & UGM & 1 & 0,66 \\
\hline 22 & $\begin{array}{l}\text { Universitas Kristen Artha } \\
\text { Wacana }\end{array}$ & 1 & 0,66 \\
\hline 23 & Universitas Majalengka & 1 & 0,66 \\
\hline 24 & $\begin{array}{l}\text { Universitas Muhammadiyah } \\
\text { Surakarta }\end{array}$ & 1 & 0,66 \\
\hline 25 & Universitas Musamus & 1 & 0,66 \\
\hline 26 & Universitas Negeri Gorontalo & 1 & 0,66 \\
\hline 27 & UNJ & 1 & 0,66 \\
\hline 28 & Universitas Negeri Padang & 1 & 0,66 \\
\hline 29 & $\begin{array}{l}\text { Universitas Pendidikan } \\
\text { Indonesia }\end{array}$ & 1 & 0,66 \\
\hline 30 & $\begin{array}{l}\text { Universitas PGRI } \\
\text { Banyuwangi }\end{array}$ & 1 & 0,66 \\
\hline 31 & Universitas PGRI NTT & 1 & 0,66 \\
\hline 32 & Universitas Sriwijaya & 1 & 0,66 \\
\hline 33 & $\begin{array}{l}\text { Universitas Tanjungpura } \\
\text { Pontianak }\end{array}$ & 1 & 0,66 \\
\hline 34 & Universitas Pattimura & 1 & 0,66 \\
\hline 35 & Unsyiah & 1 & 0,66 \\
\hline
\end{tabular}

According to the collected data, students of master's degree of Sport Science FIK UNY are consist of 1 foreign 
student $(0.66 \%)$ from University of Burundi Institute of Physical Education and Sports and 151 domestic students $(99.33 \%) .59 .21 \%$ of total amount of students are coming from UNY bachelor graduates who choose to continue their master's degree in the Faculty of Sport Science Yogyakarta State University, $3.95 \%$ (6 students) are graduated from UNNES Semarang, 3.29\% (5 students) are graduated from University of Jambi (Universitas Jambi), $2.63 \%$ (4 students) are graduated from University of Bengkulu (Universitas Bengkulu) and State University of Malang (Universitas Negeri Malang), 1.97 $\%$ (3 students) are graduated from Makasar State University (Universitas Negeri Makassar) and UNS Surakarta, $1.32 \%$ (2 students) are graduated from STKIP Dharma Wacana Metro, IKIP Mataram, UNESA Surabaya, Islamic University of Riau (Universitas Islam Riau), University of Lampung (Universitas Lampung), Mulawarman n University (Universitas Mulawarman), State University of Medan (Universitas Negeri Medan), University of Palangkaraya (Universitas Palangkaraya), University of Riau (Universitas Riau), 0.66 \% (1 students) are graduated from Gajah Mada University (UGM), UNJ Jakarta, UPI Bandung, State University of Gorontalo (Universitas Negeri Gorontalo), State University of Padang (Universitas Negeri Padang), IKIP Budi Utomo Malang, STKIP Muhammadiyah Kuningan, STKIP PGRI Pontianak, Artha Wacana Christian University (Universitas Kristen Artha Wacana), University of Majalengka (Universitas Majalengka), Muhammadiyah University of Surakarta (Universitas Muhammadiyah Surakarta), Musamus Merauke University (Universitas Musamus), Universitas PGRI Banyuwangi, Universitas PGRI NTT, University of Sriwijaya (Universitas Sriwijaya), Tanjungpura University Pontianak (Universitas Tanjungpura Pontianak), Pattimura University (Universitas Pattimura)

Table 2. Profession Before/ During Master's Degree Study in Sport Science

\begin{tabular}{|l|l|l|l|}
\hline No & $\begin{array}{c}\text { Pekerjaan Sebelum/ } \\
\text { Saat Studi S-2 Ilmu } \\
\text { Keolahragaan }\end{array}$ & Jumlah & \% \\
\hline 1 & Guru & 54 & 35,53 \\
\hline 2 & Belum Bekerja & 42 & 27,63 \\
\hline 3 & Pelatih & 13 & 8,55 \\
\hline 4 & Bekerja & 12 & 7,89 \\
\hline 5 & Dosen & 6 & 3,95 \\
\hline 6 & Personal Trainer & 4 & 2,63 \\
\hline 7 & Terapis & 3 & 1,97 \\
\hline 8 & Freelance & 2 & 1,32 \\
\hline 9 & Tenaga Pendidik & 2 & 1,32 \\
\hline
\end{tabular}

\begin{tabular}{|l|l|l|l|}
\hline 10 & Wiraswasta & 2 & 1,32 \\
\hline 11 & Program Kementrian & 1 & 0,66 \\
\hline 12 & Wasit & 1 & 0,66 \\
\hline 13 & Atlet & 1 & 0,66 \\
\hline 14 & BNN DIY & 1 & 0,66 \\
\hline 15 & Klinik Fisioterapi & 1 & 0,66 \\
\hline 16 & $\begin{array}{l}\text { Fasilator Lapangan } \\
\text { Kementrian PUPR }\end{array}$ & 1 & 0,66 \\
\hline 17 & Lembaga Keuangan & 1 & 0,66 \\
\hline 18 & $\begin{array}{l}\text { Pengelola Organisasi } \\
\text { Olahraga }\end{array}$ & 1 & 0,66 \\
\hline 19 & $\begin{array}{l}\text { Pendamping Sosial } \\
\text { PKH }\end{array}$ & 1 & 0,66 \\
\hline 20 & Telekomunikasi & 1 & 0,66 \\
\hline 21 & Media & 1 & 0,66 \\
\hline 22 & Marketing & 1 & 0,66 \\
\hline & Total & 152 & 100 \\
\hline
\end{tabular}

According to the data, profession occupied before/ during the master's degree study in Sport Science of Faculty of Sport Science Yogyakarta State University can be classified as follows: $35.53 \%$ (54 individuals) work as teacher, $27.63 \%$ (42 individuals) are not yet working, $8.55 \%$ (13 individuals) work as coach, $7.89 \%(12$ individuals) are already working, $3.95 \%$ (6 individuals) work as university lecturer, $2.63 \%$ (4 individuals) work as personal trainer, $1.97 \%$ (3 individuals) work as therapist, $1.32 \%$ ( 2 individuals) are freelance, work as educator, work as entrepreneur, $0,66 \%$ (1 individuals) works as an employee of ministry program, Referee, Athlete, Employee of National Narcotics Board in Yogyakarta, physiotherapy clinic employee, Field Facilitator for The Ministry of Public Work and Housing, Financial Firm, Sport Organization Manager, Social Companion of Family Hope Program, Telecommunication, Media, Marketing.

Table 3. Profession after graduated master's degree study in Sport Science

\begin{tabular}{|l|l|l|l|}
\hline No. & $\begin{array}{l}\text { Pekerjaan Setelah Lulus S-2 } \\
\text { Ilmu Keolahragaan }\end{array}$ & Jumlah & $\%$ \\
\hline 1 & Guru & 55 & 36,18 \\
\hline 2 & Dosen & 51 & 33,55 \\
\hline 3 & Tidak Sesuai & 23 & 15,13 \\
\hline 4 & Wiraswasta & 9 & 5,92 \\
\hline 5 & Pelatih Profesional & 7 & 4,61 \\
\hline
\end{tabular}




\begin{tabular}{|l|l|l|l|}
\hline 6 & Konsultan Olahraga & 4 & 2,63 \\
\hline 7 & Tenaga Ahli Terapi Olahraga & 2 & 1,32 \\
\hline 8 & Personal Trainer Profesional & 1 & 0,66 \\
\hline & Total & 152 & 100,00 \\
\hline
\end{tabular}

According to the acquired data, profession occupied by master's degree graduates of Sport Science study program of Faculty of Sport Science Yogyakarta State University can be presented as follows. $36.18 \%$ (55 individuals) work as teachers, $33.55 \%$ (51 individuals) work as university lecturers, $15.13 \%$ (23 individuals work in unrelated profession to their study program, 5.92 $\%$ (9 individuals) work as entrepreneurs, $4.61 \%$ (7 individuals) work as professional coaches, $2.63 \%$ (4 individuals) work as Sport Consultants, $1.32 \%(2$ individuals) work as Sports Therapy Expert, 0.66 \% (1 individuals) works as a Professional Trainer.

\section{CONCLUSION}

According to the acquired data, master's degree graduates of Sport Science study program of Faculty of Sport Science Yogyakarta State University are consist of 1 foreign student $(0.66 \%)$ who came from from University of Burundi Institute of Physical Education and Sports, and 151 domestic students $(99.33 \%)$ with the $59.21 \%$ majority (90 students) are Yogyakarta Sate University bachelor's degree graduates who choose to continue their master's degree study at Faculty of Sport Science Yogyakarta State University while 40.79\% (62 students) were came from other universities. This findings shows that the rate to continue for further study from Bachelor to master's can be categorized as good with up to $59.21 \%$ result. The majority of students who choose to continue their study in master's study of Sport Science study program of Faculty of Sport Science Yogyakarta State University are employed. The majority of students in this category is consists of 110 students $(72.36 \%)$ compared to the unemployed students category which only consist of $27.63 \%$ (42 individuals). According to the acquired data, profession occupied by master's degree graduates of Sport Science study program of Faculty of Sport Science Yogyakarta State University is consist of $36.18 \%$ (55 individuals) work as teachers, $33.55 \%$ (51 individuals) work as university lecturers, $15.13 \%$ (23 individuals work in unrelated profession to their study program, $5.92 \%$ (9 individuals) work as entrepreneurs, $4.61 \%$ (7 individuals) work as professional coaches, $2.63 \%$ (4 individuals) work as Sport Consultants, $1.32 \%$ (2 individuals) work as Sports Therapy Expert, $0.66 \%$ (1 individuals) works as a Professional Trainer.

\section{REFERENCES}

[1] J. Aliu and C. O. Aigbavboa, "Structural determinants of graduate employability: impact of university and industry collaborations," $J$. Eng. Des. Technol., vol. 19, no. 5, 2020, doi: 10.1108/JEDT-05-2020-0189.

[2] H. P. Nudzor and F. Ansah, "Enhancing postgraduate programme effectiveness through tracer studies: the reflective accounts of a Ghanaian nation-wide graduate tracer study research team," Qual. High. Educ., vol. 26, no. 2, 2020, doi: 10.1080/13538322.2020.1763034.

[3] . K., A. Purwito, and P. Muljono, "The Major Minor Curriculum Application in Preparing the Communication Science and Community Development Graduates to the World of Work: Graduates Perception (Case Study in Bogor Agricultural University, West Java, Indonesia)," J. Educ. e-Learning Res., vol. 4, no. 3, 2017, doi: 10.20448/journal.509.2017.43.100.107.

[4] R. Akbar and M. Mukhtar, "Evaluasi e-Tracer Study menggunakan HOT (Human-

Organization-Technology) Fit Model," J. JTIK (Jurnal Teknol. Inf. dan Komunikasi), vol. 3, no. 2, 2019, doi: 10.35870/jtik.v3i2.86.

[5] R. Akbar and M. Mukhtar, "Perancangan ETracer Study berbasis Sistem Cerdas," $J$. Sisfokom (Sistem Inf. dan Komputer), vol. 9, no. 1, 2020, doi: 10.32736/sisfokom.v9i1.631.

[6] R. Indonesia, Undang-Undang RI Nomor 12, Tahun 2012, Tentang Pendidikan Tinggi. 2012.

[7] S. Mukrodin, "Implementasi Metode Waterfall Dalam Membangun Tracer Study Dan Penerimaan Peserta Didik Baru," J. Din. E-ISSN 2623-1786| P-ISSN 0854-9524, vol. 25, no. 1, 2020.

[8] K. Harianto, H. Pratiwi, and Y. Suhariyadi, "Sistem Monitoring Lulusan Perguruan Tinggi Dalam Memasuki Dunia Kerja Menggunakan Tracer Study," J-SAKTI (Jurnal Sains Komput. dan Inform., vol. 3, no. 2, 2019, doi: 10.30645/jsakti.v3i2.148. 